\title{
$\begin{array}{llllllll}\boldsymbol{R} & \boldsymbol{a} & \boldsymbol{s} & \boldsymbol{p} & \boldsymbol{r} & \boldsymbol{a} & \boldsymbol{v} & \boldsymbol{e}\end{array}$
}

\section{KRŠĆANSKI WELTANSCHAUUNG I ETIKA KOD ROMANA GUARDINIJA}

\author{
Carmelo Dotolo
}

Pontificia Università Urbaniana

UDK: 17:272-184.3]Guardini, R.2-05

Roma, Italia

dotolo@carmelodotolo.eu

Izvorni znanstveni rad Primljeno 03/2019.

\section{Sažetak}

Jedna od zasluga razmišljanja Romana Guardinija jest da je pridonio boljem ocrtavanju teološkog promišljanja dvadesetog stoljeća i njegova epistemološkog statusa, ponajprije $u$ interdisciplinarnoj pozornosti i logici dijaloga. U tom smislu, hermeneutička figura Weltanschauunga čini se plodnom, sa zanimljivim razvojem: ona poziva teologiju da razmišlja o sebi i ponaša se kao intelektualni partner među ostalima, pokazujući teoretski identitet koji se može postaviti na granicu znanja koje u srcu ima razumijevanje otajstva stvarnog. Iz te perspektive religiozno iskustvo pridonosi drugačijem razumijevanju ljudskog stanja, otvarajući ga objavi kao nužnom uvjetu za pokretanje potrage za nekim važnim ključevima čitanja u tumačenju svijeta i povijesti. To donosi barem dvostruku posljedicu. Prva je tvrdnja o objavljujućoj strukturi stvarnosti u kojoj se religija pojavljuje kao poseban način nastanjivanja svijeta, u kojem se oblikuju pitanja i obzorja egzistencije. Druga je pokazatelj „kršćanske kulture“ kao radikalne i jedinstvene perspektive o čovjeku, svijetu, povijesti, koja na temelju uskrsnog događaja postaje proročanstvo smisla u sociokulturnim procesima.

Ključne riječi: Guardini, Weltanschauung, etika, teološko promišljanje, religiozno iskustvo 


\section{UVOD}

Jedna od značajki teološkog promišljanja (i ne samo) dvadesetog stoljeća nalazi se u stalnom ponovnom kalibriranju metode i potrebe za promjenom paradigme, ${ }^{1}$ nadasve $u$ odnosu na pitanje složenosti hermeneutike stvarnosti koja je povećala promišljanje teologije i njezinih interpretativnih modela. Nije slučajno da je odraz R. Guardinija smješten u prostoru negostoljubive konjunkture koja je prešla teološku refleksiju dvadesetog stoljeća i njezin epistemološki status, potaknuta dijaloškom usporedbom s različitim kognitivnim modulima u čitanju svijeta, povijesti, postojanja. ${ }^{2} \mathrm{U}$ tom smislu, Guardinijevo djelo karakterizira dragocjena heuristička sposobnost koja se može pripisati hermeneutičkoj figuri Weltanschauunga. ${ }^{3}$ Ona poziva teologiju da promišlja i ponaša se kao intelektualni partner među ostalima, pokazujući teoretski identitet koji je u stanju smjestiti se unutar granica znanja koja na srcu imaju istraživanje i razumijevanje otajstva stvarnosti.

\section{Semantika WeltanschauUnga}

„Pitanje koje me mučilo (1923.) bilo je sljedeće: je li još uvijek moguć, usred svega što se događa, tip života koji se u potpunosti temelji na prirodi i čovjekov radu?"4 Pitanje predstavljeno u $I X$.

1 Za analizu povezanosti teološkog promišljanja i promjene paradigme vidi: $H$. Küng - D. Tracy (prir.), Das neue paradigma von Theologie. Strukturen und Dimensionen, Benzinger Verlag - Gütersloher Verlaghaus, Zürich -Gütersloh Einsielden, 1986.

2 Za jedan opći pogled vidi: C. Dotolo, Romano Guardini, u: Storia della teologia 3. Da Vitus Pichler a Henri de Lubac, a cura di R. Fisichella, ED-EDB, Roma Bologna, 1996., 717-733.

3 Znakovito je što o pojmu Weltanschauunga piše sam Guardini: „Pojam Weltanschauung je problematičan. Svatko tko želi ispričati priču o ovom problemu, trebao bi ispričati četiri stoljeća povijesti duha. Priča koja se gotovo podudara s onim procesom $u$ kojem se vjerovanje $u$ biblijsku objavu i tumačenje postojanja na temelju nje više nije osjećalo univerzalno valjanim te su umjesto božanski utemeljene sigurnosti preuzete subjektivne vizije svijeta. Te su vizije tada postajale sve više i više neodređene: sve više i više gubile ono što je istinski obvezujući karakter istine, presudno za postojanje.“ R. Guardini, Ansia per l'uomo, Morcelliana, Brescia, 1970., 155. Za prvu i opširniju informaciju o pojmu Weltanschauung vidi: T. Manferdini, Weltanschauung. Religione e fede in Romano Guardini, u: La Weltanschauung cristiana di Romano Guardini, a cura di S. Zucal, EDB, Bologna, 1988., 257-352; S. Zucal, Visione cattolica nel suo tempo, u: R. Guardini, la visione cattolica del mondo, Morcelliana, Brescia, 1994., 49-99.

4 R. Guardini, Lettere dal lago di Como, Morcelliana, Brescia, 1959., 88-90. 
Pismu s jezera Como (jesen 1925.) ukratko izražava intencionalnost teorijskog istraživanja talijansko-njemačkog teologa: identificiranje Weltbilda sposobnog smjestiti globalni smisao postojanja i redizajn identiteta čovjeka u složenosti povijesti. Razlog leži u činjenici što je ljudsko oblikovanje Weltbilda događaj koji se hrani vrijednostima, načelima, izborima koji impliciraju aksiološki stav čovjeka u odnosu na svijet, njegovo zauzimanje stava. Otuda raznolikost odgovora na pitanje o značenju svijeta koji određuje način na koji se živi povijest, interpretirajući ga prema pogledu koji određuje put. I to je vjerojatno srž hermeneutike stvarnosti: pogled, to jest kognitivni pristup, surađuje u konstrukciji slike svijeta kroz posebnost okretanja prema ukupnosti stvari. ${ }^{5}$ Stoga ne čudi što različite vizije svijeta ukazuju na način orijentiranja i donošenja posljedičnih odluka s obzirom na svijet i povijest, uzrokujući procjenu koja se oblikuje u različitim čitanjima stvarnosti. Da su znanost, filozofija, književnost, povijest kognitivni putovi svijeta i čovjeka, evidentna je činjenica u procesima kulturne razrade. Ipak, takvo znanje izražava interpretativne modele čije razumijevanje mora računati s posebnostima metoda istraživanja i perspektivom koja riskira potpuni gubitak darovanosti stvari. U tom smislu, način gledanja na stvarnost nije ravnodušan prema njezinu shvaćanju, jer u kognitivnoj orijentaciji u igri je sposobnost mjerenja i vaganja stvarnog u svom semiotičkom i simboličkom bogatstvu. Rezultat je dvostruko važna metodološka posljedica.

Na prvome mjestu, Weltanschauung oblikuje kognitivno držanje u kojem privremene ukupnosti u sebi žive od odnosa prema konačnim i zaključnim ukupnostima. To podrazumijeva da Weltanschauung nastoji zahvatiti cjelinu tako da je ne apstrahira od njezine bitne konkretnosti, kako bi se, također, izbjegla teoretska razrada koja gubi iz vida osobitost kao uvjet samog poznavanja. To je, naposljetku, fenomenološki proces koji podsjeća na danost stvari i svijet u njegovu nuđenju pogledu. ,Weltanschauung je dakle pozicija koju zauzima onaj koji promatra svijet koji mu dolazi ususret." ${ }_{6}$

Drugo, pojavljuje se etička konotacija Weltanschauunga zbog zadatka koji svijet postavlja čovjeku. Ona zahtijeva odgovarajuću sposobnost čitanja stvarnosti, za koju se proces društvene kon-

5 Ovako piše Guardini: "Što podrazumijevamo kad govorimo o Weltanschauungu? Pod tim shvaćamo kognitivni pokret okrenut, na posve poseban način, prema ukupnosti stvari, na ono što ima 'značaj svijeta' u danoj stvarnosti [...] Konačno, čin Weltanschauunga znači istodobno procjenjivanje, mjerenje i vaganje; stav $u$ odnosu na zadatak koji je taj isti svijet postavio onome koji to misli." La visione cattolica del mondo, 16.

$6 \quad$ R. Guardini, La visione cattolica del mondo, 20. 
strukcije svakodnevnog života ne može odvojiti od poziva koji stvarnost predstavlja prije svake njezine klasifikacije i označavanja i rizika naivnih projekcija značenja. Drugim riječima, stvarnost u svojoj ukupnosti pokazuje se kao stvarnost čijoj konfiguraciji pridonose tri složene ukupnosti: ukupnost svijeta kao sinteza stvari i vanjskih činjenica; sam čovjek kao pojedinac i zajednica; Bog, temelj i podrijetlo, arhetip (Urbild) koji izaziva događaj susreta kao modalitet odnosa. ${ }^{7}$

\section{RELIGIOZNO ISKUSTVO I HERMENEUTIKA EGZISTENCIJE}

Ako, dakle, prikladna vizija svijeta namjerava presresti značenje koje ga konstituira, nužno je učiniti priziv na ukupnost svijeta u njegovim strukturnim sastojcima, među kojima se nalazi i religiozno iskustvo u svoj svojoj problematičnosti. Samo religiozno iskustvo ${ }^{8}$ tematizira ne-očiglednost svijeta; naprotiv, problematizira je, omogućujući joj drugačiju perspektivu te lomeći naivnu spoznajnu sigurnost realizma koji je vlastit moderni, ${ }^{9}$ čji je proces transformacije

7 Guardini se pita: „Gdje je ta ukupnost? Nalazi se, najprije, u svakoj pojedinoj stvari, kada je viđena upravo s 'likom svijeta'. Potom, nalazi se u složenoj ukupnosti. One su tri, ukoliko, uostalom, nisu na istoj liniji. Prije svega, ukupnost svijeta kao zbirka vanjskih stvari i činjenica, kojima čovjek također pripada prema svom fizičkom biću. Potom sam čovjek, ukoliko u sebi samome oblikuje konačno jedinstvo, i kao pojedinac i kao zajednica, stoji nasuprot svijeta. Naposljetku, temelj i apsolutno podrijetlo čovjeka i svijeta: Bog. Na te tri složene ukupnosti okrenut je pogled Weltanschauunga, i na pojedinačne stvarnosti, ukoliko su uključene u njih“. La visione cattolica del mondo, 24.

8 Usp. A. Rigobello, Esperienza, fenomenologia e dialettica in Romano Guardini, u: Romano Guardinie la visione cristiana del mondo, Gregoriana, Padova, 1989., 64-67.

$9 \quad$ Kao što je poznato, čitanje modernosti (ili višestrukih itinerarija modernizacije) predstavlja quaestio disputata o genealogiji njezina puta prekida i krize s obzirom na auctoritates, među kojima je i kršćanska religija. Hermeneutički sukob između sekularnog prevođenja teoloških kategorija i načela samo-legitimacije modernosti predstavlja teorijsku spojnicu kako bi se shvatio nagli proces sekularizacije kao diskriminirajuće točke bliskosti i / ili udaljenosti između modernosti i kršćanstva. Ovo nije mjesto za odgovarajuću studiju. Također treba reći da se perspektiva guardinijevskog čitanja usredotočuje na kraj modernog doba shvaćenog kao fragmentacija Weltanschauunga zbog kognitivnog prioriteta subjekta koji dekonstruira logiku susreta u programskoj samoreferencijalnosti. Tako, primjerice, Guardini, u La fine dell'epoca moderna. Il potere, piše: „Tko razmatra stvarnost bez predrasuda, lako prepoznaje da se konačnost bića podudara $s$ činjenicom da je stvoreno; može shvatiti kako je značaj objave sadržan u svakom biću te odatle stići do odlučnog prihvaćanja biblijske Objave. Iz toga bi proizišla religioznost posve lišena sentimentalizma te posve realistična. Ona se više ne bi kretala unutar fragmentarne prirode psihološke unutrašnjosti ili religioznog idealizma, već unutar stvarnosti, koja je, budući da je integralna, također stvorena 
svijeta predstavljao jednostranu i često nekritičku prekretnicu ljudske egzistencije. Znanstvena slika svijeta postala je preciznija, ali se ipak ne čini da se u njoj čovjek još uvijek osjeća kao kod kuće, baš kao što se, u neposrednom osjećaju, čini da Bog još nema dom u svijetu. ${ }^{10}$

Talijansko-njemački teolog oštro postavlja problem, ističući da religiozno iskustvo ${ }^{11}$ predstavlja kognitivni pristup stvarnosti koji se ne može svesti na teorijski deficit ili psihološke projekcije. Takve ideološke procjene štite razumijevanje religijskog fenomena kao poseban način da se bude dotaknut egzistencijom, čija singularnost leži u kontaktu s čudesnim, nepoznatim, svetim, koji potiču istraživanje iznad očitosti. Religija pokazuje sadržaje i motive koji djeluju s čovjekom u njegovoj cjelovitosti, jer se odnosi na napor postojanja, osobito u pronalaženju i provedbi njegova značenja. Ostaje, međutim, činjenica da se religiozno iskustvo, ma kako duboko, može iscrpiti u neposrednosti, u najpoželjnijem odgovoru, budući da je čovjek time obdaren; gotovo da je riječ o potrebi za kulturnom razradom $\mathrm{s}$ obzirom na društvene i životne pritiske. I to je razlog zašto su religije uvijek predmet interesa, ali i nerazumijevanja ${ }^{12}$ izazvana njihovim predstavljanjem kao terapijskog i etičkog rješenja koje se čini malo vjerojatnim i nadasve naivnim. Koliko god to moglo odgovarati stvarnosti, guardinijevsko promišljanje inzistira na sljedećem: vjersko iskustvo ne odgovara zahtjevima koji su već definirani kulturnim

od Boga, od njega očuvana te intimno upravljana Njegovom voljom." R. Guardini, u La fine dell'epoca moderna. Il potere, Morcelliana, Brescia, 1993., 202.

10 R. Guardini, La fine dell'epoca moderna, 50.

11 Usp. R. Guardini, Fede - Religione Esperienza. Saggi teologici, Morcelliana, Brescia, ${ }^{2}$ 1995., 53-96.

12 Guardinijevsko inzistiranje na dvosmislenosti i složenosti religioznog iskustva lajtmotiv je njegova razmišljanja, budući da religija ima simboličku moć i kreativnu maštu unutar društveno-kulturnih procesa koji nisu indiferentni prema organizaciji postojanja. Vidi, primjerice, promišljanja nastala iz dubokog razgovora s poezijom Friedricha Hölderlina: R. Guardini, Hölderlin. Immagine del mondo e religiosità, I, Morcelliana, Brescia, 1995., 435-449. Naglasak je stavljen na rizik izvođenja religije iz straha i antropološke nesigurnosti, kao da bi se pokazala njezina privremenost $\mathrm{u}$ evolutivnom razvoju ljudske povijesti. Nasuprot tome, vjerska stvarnost prema Guardiniju mora se tumačiti kao nešto bitno i značajno za ljudsko istraživanje, čak i ako je izloženo mogućnosti njezina poricanja ili perifernosti u razradi smisla. Evo što o tome piše Guardini: „Iz toga proizlazi u prvom redu činjenica da je religiozni fenomen vrlo složen i zasićen svom problematičnošću i dvosmislenošću ljudskog postojanja. Međutim, tu se dvosmislenost ne će moći riješiti pripisujući je religioznom fenomenu kao takvom, umjesto da ju se shvati polazeći od ukupne situacije čovjeka; prije svega izbjegavanjem pogrješke prema kojoj smisao fenomena ovisi o načinu na koji se pojavljuje ili o mogućim degenerativnim oblicima." R. Guardini, Religione e rivelazione, Vita e Pensiero, Milano, 2001., 83. 
kanonima i društvenim praksama, jer njegovoj biti pripada „dojam da njegov objekt ne ulazi u nešto što je jednostavno dano svijetu; da je umjesto toga tajanstven, neizreciv, drugi, da dolazi od drugdje i vodi negdje drugdje“. ${ }^{13}$ Religija i religije priznaju, u raznolikosti svojih izraza, da one predstavljaju odgovor na poziv, poziv koji se konfigurira u iskustvu slušanja i u percepciji izražajnog i simboličkog značenja stvarnosti. Drugim riječima, potvrđuju da svaka diskurzivna mogućnost o božanskom ili o Bogu i posljedična razrada vlastitog identiteta nisu izgrađeni počevši od sebe samih, već iz događaja koji ih otvara istraživanju. Nije nevažno isticati tu dimenziju, jer upozorava da je, iznad svakog odstupanja od izvorne intencionalnosti, religiozno i vjerujuće iskustvo na tragu Nekoga, numinoznog Otajstva koje poziva na postojanje. Nema sumnje da je to izraz čovjekova radikalnog nemira ili znak prolaznosti koja kao da ugrožava dosljednost života. Međutim, kršćanska konotacija religijskog iskustva nadilazi „naravnu“ religioznost u simbolici vjere kao razumijevanja i tematizacije nove paradigme stvarnosti. Ta vjera je nešto bitno drugo od bilo kojeg „religioznog iskustva“. Ono što proizlazi iz nje, vjerničko postojanje sa svojim poretkom, nešto je po svojoj biti različito od bilo koje „religije“, tako da se, uzeta kao krajnji slučaj, čini mogućom vjera bez iskustva, u smislu osobne potresenosti; gola vjera poslušnosti. Ta razlika pripada biti kršćanske svijesti. ${ }^{14}$

\section{OBJAVA KAO NEOBJAVLJENI WELTANSCHAUUNG}

Ukoliko su odgovor na apel koji poziva na antropološku decentralizaciju, utoliko religije znaju i tematiziraju leksik objave kao događaj značenja, otkriće različitosti dara koji se događa. Nije slučajno da je od Dei Verbum ${ }^{15}$ teološko promišljanje inzistiralo na epistemološkom statusu pojma objave. Ponovno otkriće kategorije objave kao kritičkog i determinantnog koncepta tumačenja kršćanstva,

13 R. Guardini, Religione e rivelazione, 79.

14 Usp. R. Guardini, Religione e rivelazione, 81-82. O tim vidovima Guardinijeva promišljanja vidi: G. D’Acunto, Romano Guardini. Concretezza e opposizione, Urbaniana University Press, Città del Vaticano, 2014., 63-75.

15 O tome postoji opširna bibliografija. Upućujemo samo na neka djela: R. Fisichella, La rivelazione: evento e credibilità. Saggio di teologia fondamentale, EDB, Bologna, ${ }^{6}$ 1997.; B. Sesboüé, La comunicazione della Parola di Dio: Dei Verbum, u: Isti (a cura di), Storia dei Dogmi IV. La Parola della Salvezza, Piemme, Casale Monferrato, 1998., 449-491; J. Werbick, Essere responsabili della fede. Una teologia fondamentale, Queriniana, Brescia, 2002., 349-357; C. Theobald, "Seguendo le orme... " della Dei Verbum. Bibbia, teologia e pratiche di lettura, EDB, Bologna, 2011 .; F. Testaferri, "Il tuo volto Signore io cerco“. Rivelazione, fede, mistero: una teologia fondamentale, Cittadella Editrice, Assisi, 2013., 179-197. 
mora se shvatiti kako bi funkcioniralo kao ujedinjujući princip, ${ }^{16}$ duž složene i artikulirane putanje koja vidi različite putove pristupa: od objave kao poziva koji dislocira i pomiče subjekt na prag Drugoga, do objave kao nužnog uvjeta u potrazi za antropološkim identitetom; od objave kao eshatološke razlike koja utiskuje višak značenja $\mathrm{i}$ istine u pretposljednjem, do objave kao točke gledišta koje se može preuzeti iz povijesti o Isusu (christliche Weltanschauung), a koja na izvoran način mijenja hermeneutički zahtjev za tumačenjem svijeta i povijesti. Posljedica tog procesa je da objava kao samo-priopćenje u povijesti Isusa Krista postaje polaznom točkom teološke refleksije (Reflexionbegriff ${ }^{17}$ ) koja inaugurira zanimljiv način razmišljanja i življenja. Sinteza toga izražena je u Fides et ratio, br. 14: „Objava uvodi neku točku nužnosti bez koje čovjek ne može biti ako hoće doprijeti do razumijevanja otajstva svoga života; no s druge strane, ova spoznaja neprestano upućuje na Božje otajstvo koje duh ne može sasvim iscrpsti, nego samo opaziti i u vjeri obuhvatiti. [...] Objava u našu povijest unosi onu opću i posljednju istinu, koja potiče ljudski duh da se nikada ne zaustavi; dapače, tjera ga da stalno širi granice svoje spoznaje, dok ne shvati da je učinio sve ono što bijaše u njegovoj moći, a da ništa nije zanemario.“

Međutim, povijest takvog pojma stvorila je neke teorijske probleme, zbog činjenice da se za neke tumače religije upotreba kategorije objave čini nekontroliranom, kao vrsta znanja koje dolazi izvana i koje krši kognitivnu autonomiju subjekta. Naposljetku, kako netko može prihvatiti religiju koja nije unutar granica razuma? To je osjetljivo pitanje, jer ako događaj objave ima što reći, to je samo u naznaci iznenađujuće i neočekivane razlike: da Drugi / Bog koji se otkriva nije samo drugačiji, svet, otajstven, nego te kategorije još uvijek pripadaju dijalektičkoj napetosti čovjekova svijeta. Događaj objave usmjerava religiozno iskustvo na autentičan način, pozivajući ga da se suoči s pravim Bogom koji izlazi iz čiste neshvatljivosti i ne mjeri se spoznajnim potrebama čovjeka. Ako je opravdan prijevremeni zaključak, taj bi išao u smjeru središnjeg značenja pojma objave koja, u svojoj biti, govori o provali drugotnosti koja je vlastita Bogu kao uvjeta za prihvaćanje vjere. U toj odnosnoj dimenziji ${ }^{18}$

16 Usp. P. Eicher, Offenbarung. Prinzip neuzeitlicher Theologie, Kösel, München, 1977., 48-57.

17 Usp. M. Seckler, Il concetto di rivelazione, u: W. Kern - H.J. Pottmeyer - M. Seckler (prir.), Corso di Teologia Fondamentale 2. Trattato sulla Rivelazione, Queriniana, Brescia, 1990., 66-94.

18 Usp. P. Schmidt-Leukel, Sulla credibilità dell'annuncio cristiano, La Scuola Cattolica, 125 (1997.) 472, govori o objavi kao epistemološkom pojmu odnosa; W. Jeanrond, Rivelazione e concetto trinitario di Dio: idee principali del pensiero 
objava zahtijeva propedeutičku asimetriju u odnosu na konstrukciju religioznog iskustva, kada se nudi kao neprisilan poziv koji u Isusu Kristu postaje paradoksalni prijedlog za nov način razumijevanja drugih iskustava objave. ${ }^{19} \mathrm{U}$ toj perspektivi za Romana Guardinija objava predstavlja teoretsko i etičko podrijetlo kršćanskog Weltanschauunga; štoviše, ono što hrani način gledanja na povijest i postojanje ne na akcidentalan, nego na planski način. „Weltanschauung je slika svijeta kakav proizlazi s točke gledišta Objave; skup onih pojašnjenja koja neposredni problemi svijeta dobivaju iz Objave - i obrnuto, ona ukazuje na sadržaj onih odgovora na koja je Objava potaknuta pitanjima svijeta. “20

Razlog tome leži u njezinoj neizvodivosti, ne-predodređenoj početnoj točki koja pripravlja znanje za prijam, koja nadilazi zdrav razum i okvire nužnoga. Razlog leži u „istinskom drugom“ Boga koji u kršćanskoj perspektivi dopušta da ga se susretne u povijesnom događaju Isusa Krista. Takva iznimka koja oblikuje samu bit kršćanstva, za filozofsku misao predstavlja prepreku koja se ne može lako zaobići, budući da premješta os razmišljanja na odnos povijest-apsolutnost. Na taj se način događa kognitivna promjena jer se „ta Božja stvarnost ne može shvatiti samo s kategorijama 'apsolutnosti'; moraju se dodati i one 'činjeničnosti'. Živi Bog je zaista takav da odlučuje, da ustaje, dolazi, govori, djeluje, ljuti se, primiruje se, kaje se, oprašta. Objava je dakle način na koji On govori u 'vremenu', a vjera je specifičan ljudski čin koji tome odgovara."21

$\mathrm{S}$ te točke gledišta kršćanstvo je novost $\mathrm{u}$ povijesti religija. ${ }^{22}$ Ono preoblikuje religiozno iskustvo, vodeći ga u neobičan prostor

teologico?, Concilium, 37 (2001.), 162, primjećuje kako se govor Drugog vatikanskog koncila o objavi temelji na pojmu odnosa.

19 Pietro Coda veli da se „kristološka objava predstavlja kao hermeneutički ključ, subjektivno i objektivno prikladan, za razumijevanje istine i drugih iskustava 'objave', što se, po pravu, može i treba dogoditi ne u izvanjskom i redukcionističkom obliku, nego stvarno poštujući njihovu izvornost“. P. Coda, Il logos e il nulla. Trinità religioni mistica, Città Nuova, Roma, 2004. ${ }^{2}, 136$.

20 R. Guardini, Religione e rivelazione, 11.

21 R. Guardini, Fede - Religione Esperienza, 88.

22 O prisutnosti objave u religijama i važnosti znanosti religija za teološku refleksiju usp. P. Tillich, Il futuro delle religioni, Queriniana, Brescia, 1970., 118-137. U četvrtom Bampton Lectures, održanom u Low Memorial Library na Sveučilištu Columbia (1961.), Tillich sugerira, između ostalog, princip samorazumijevanja kršćanstva u dijalogu s velikim religijama koji se usredotočuje na posebnost kršćanskog događaja koji oslobađa njegov lik iz povezanosti s religijskom sferom. On veli: "Prva je napetost između posebnog i općeg značaja kršćanske tvrdnje; druga je napetost između kršćanstva kao religije i kršćanstva kao negacije religije. Obje ove napetosti proizlaze iz naravi događaja na kojem se temelji kršćan- 
povijesnosti Boga, gdje se ono više što nadilazi samo očekivanja religioznog nalazi u promišljanju Isusa Krista kao onog koji otvara stvarnost kao odnos s božanskim. U tom smislu, biblijsko-kršćanska objava ne predstavlja rez $\mathrm{u}$ odnosu na pripadnost religijskom fenomenu, već kvalitativni iskorak.

\section{ONO VIŠE OBJAVE I NERAZMJER VJERE}

Prema tome, kršćanstvo proizvodi šok koji nije lako prihvatiti, koliko god bio oslobađajući, zbog činjenice da on inaugurira oblik postojanja koji se više ne okreće sebi samome. To je kritična točka događaja kršćanskog vjerovanja, koja križa dijalektiku između svjetovnog i religioznog, svetog i profanog, potičući je prema stvarno drugom pozivu koji iznenađuje čovjeka u tajni njegova identiteta. Učinak nije nevažan. On slabi mirnu religioznu vezu i potkopava želju za vjerovanjem koje se čini pomirljivim s obzirom na perspektivu znanja koje cilja psihološkoj, kulturnoj i etičkoj zrelosti. Prihvatiti objavu, znači postati svjestan početka i, možda, stalne dezorijentacije religiozne imaginacije i njezinih očekivanja i povlastica. U tome možemo shvatiti tu artikuliranu dinamiku vjerovanja koja koegzistira $\mathrm{s}$ nevjerom, sa sumnjom, s krizom svake sigurnosti, potaknuta na drugačije mišljenje, koje Božja riječ u Isusu pobuđuje u zagonetki postojanja. Iz tih razloga, vjerovanje živi u paradoksu svoga kretanja, a čin vjere mora se nositi s nerazmjerom, ponekad nepremostivim: onim između Weltanschauunga kao iskustva događaja koji vodi čovjeka do praga otajstva njegova bića i uzaludnog napora da razmisli i razradi njegov sadržaj. „Povijest vjere u svijet odvija se u procesu koji pokazuje koliko je ona stvarno kadra uzeti u svoju službu ovaj svijet oblika i značenja, revidirati njegov sadržaj, ali istodobno ostati budna u svojoj odgovornosti prema Objavi, ili koliko je naprotiv uključena u preobražaj. “23

Ako je tako, tada valja premisliti hipotezu koja kaže kako je vjera u Objavu izbor koji umanjuje autonomiju i proces individualnosti svakog muškarca i žene. U susretu između Boga i čovjeka događa se

stvo. Značenje 'kršćanskog događaja' ne leži u stvaranju temelja za novu posebnu religiju,... već se sastoji u samom događaju. To je osobni život koji je utisnut u njegove sljedbenike kao slika neprekinutog odnosa s Bogom, i koji ne traži ništa za sebe, za svoju osobitost. Ono što u Kristovu liku daje vrijednost osobitog, jest to što je on razapeo osobito u sebi samome zbog općeg. To je ono što oslobađa njegovu sliku od povezanosti s određenom religijom - religija kojoj je pripadao njega je izopćila - i iz veze s religioznom sferom kao takvom ." P. Tillich, Il cristianesimo e le religioni e Riflessioni autobiografiche, Mursia, Milano, 1971., 147.

R. Guardini, Fede-Religione Esperienza, 83. 
nešto nepredvidivo, jer se radi o konkretnosti života i ljudskom iskustvu nečega što čovjeku pomaže da se razumije i ostvari. ${ }^{24}$ Gotovo da se dolazi do toga da se može biti ono što jesmo samo polazeći od Boga, izvan svake mašte. Pred uvijek novim povijesnim procesom Objave i njegova razumijevanja, čovjek je pozvan trajno se stavljati $\mathrm{u}$ iščekivanje nevjerojatnog i ne-vjerujućeg koje hrani put slobode, koja se ne predaje pred pojavama života. Objava, naposljetku, djeluje kao uvjet otkrivanja stvarnosti i umeće se u najvažnije interese svakog muškarca i žene, nudeći drugačije tumačenje kršćanskog paradoksa čovjeka. Ako je kršćanstvo, dakle, putokaz za otkrivanje značenja, to je zato što poziva egzistenciju da ozbiljno prihvati stvarnost svijeta kao znak drugotnosti koja se upisuje u konkretnost povijesnih procesa. To je gotovo promjena ljestvice u mjerenju stvari, osobito kada život postaje problematičan, gurnut izvan sebe u smjeru u kojem je moguće otkriti mjesta smisla: identitet, sloboda, sudbina, autentičnost. ${ }^{25}$ U konačnici, Objava se predstavlja kao referentno obzorje čovjekova egzistencijalnog napora, budući da je čovjeku ponuđena mogućnost da povrati svoje izvorno zvanje, odnosno poziv na odgovornost da bude osoba u projektu stvaranja. Stoga događaj Objave udara na čovjekovu kognitivnu spontanost: ona se susreće s putovima ljudskog istraživanja, potičući je da bude više interpretativna te je pozivajući da ostane u čuđenju razuma pred objavom otajstva: „Bog je onakav kakav se pojavljuje u Objavi. Nema Boga čiste nepojmljivosti, Boga neodređenosti, kojeg bi svatko trebao samo po sebi odrediti. Bio bi to Bog što ga čovjek stvara prema vlastitoj mjeri kako bi izbjegao odluku. Stvarni Bog je onaj koji se je odlučio te je upravo tako pozvao čovjeka da se odluči pred Njim.“26

24 Guardini se često vraća na promišljanje o temi čovjekova samorazumijevanja; posebno naglašava kako bez susreta s Bogom humana conditio ostaje nerazumljiva enigma. U jednom djelu piše: „Da jesam shvaćam samo na temelju onoga što je iznad mene. Štoviše: u Onome koji me je dao meni samome. Čovjek se ne može shvatiti polazeći od sebe samoga. Na pitanja u kojima se pojavljuje riječ 'zašto' i riječ ‘ja': zašto sam takav kakav sam? zašto mogu imati samo ono što imam?, zašto jednostavno jesam umjesto da budem?, ne može se odgovoriti polazeći od čovjeka. Odgovore na ta pitanje daje samo Bog." R. Guardini, Accettare se stessi, Morcelliana, Brescia, 1992., 29.

25 U knjizi Fede - Religione Esperienza Guardini piše: „Doista, u istini, s vjerom prihvatiti baštinu Objave nije hladna konstatacija jedne objektivne situacije, nego živo povezivanje stvarnosti sa Stvarnošću; to je predanost, veza, povjerenje, jedinstvo i stoga se ne oslanja toliko na procjenu i živu percepciju dragocjenosti koliko na točnu prosudbu o objektivnoj situaciji“. R. Guardini, Fede-Religione Esperienza, 28.

26 Usp. R. Guardini, Fede-Religione-Esperienza, 194. 


\section{POLAZEĆI OD WeLtansCAUUNGA. ZAKLJUČNA PROMIŠLJANJA}

Ako kršćanska vizija svijeta uspostavlja određenu hermeneutičku dinamiku, to je zato što sugerira neviđenu topologiju povijesti, u kojoj odnos između Boga i čovjeka čini uvjet mogućnosti drugačijeg načina življenja egzistencije. I to, polazeći od pogleda Isusa Krista „doista punog Weltanschauunga. Pogled Weltanschauunga je Kristov pogled“. ${ }^{27} \mathrm{Na}$ temelju tog teorijskog okvira Guardianijevo promišljanje nudi dvostruko, odlučujuće tematsko obzorje teološko-filozofskom promišljanju.

a) Na prvoj razini, to je potvrda objavljujuće strukture stvarnosti. Iako su postojanje, svijet, povijest obilježeni neprozirnošću tipičnom za konačnost, istodobno signaliziraju nesigurnost autoreferencijalnog čitanja stvarnosti. Objava, naprotiv, kao vizija svijeta, svojom heterogenošću potiče na drugačiji pogled, problematizirajući činjeničnu očitost. Drugim riječima, neiscrpno značenje objave, njezin uvijek iznenađujući događaj, vodi istraživanje iznad normativnosti činjenica, ako ne čak i bez nje, upravo zato što anticipira i iznenađuje percepciju stvarnosti i njezina iskustvo. ${ }^{28} \mathrm{Na}$ toj je razini artikulirana teološka dimenzija objave koja, govoreći kako je religiozno iskustvo iskustvo postojanja otvorenosti Bogu, istodobno izražava ideju da je stvarnost satkana od odnosa, u liku saveza koji je usmjeren prema dinamizmu i konačnosti same stvarnosti. Ako, dakle, religiozno iskustvo uvodi nesuglasje u čitanje stvarnog, ono to ne čini kako bi stvorilo kontrapoziciju, nego kako bi ukazalo na osobit susret sa stvarnošću. Uostalom, religija nije drugo doli poseban način življenja u svijetu u kojem se oblikuju pitanja i obzorja egzistencije, otvarajući se traganju usmjerenom prema tematiziranju nove paradigme stvarnosti.

b) Na drugoj razini, etička krivulja Weltanschauunga postavlja pitanje kulturne odgovornosti kršćanstva, odgovornosti koja je dio izgradnje društvenog i političkog svakodnevnog života i koja otvara mogućnost „kršćanske kulture“. Ako pogled i rad čovjeka prožimaju stvarnost, to predstavlja kulturni događaj, usmjeren na perspektivu smisla koji se trudi probiti izvan situacija, u želji i pokušaju iznalaženja egzistencije. Dakle, izvan predrasuda prosvjetiteljstva, kršćanstvo nudi radikalnu i jedinstvenu perspektivu o čovjeku, svi-

27 Usp. R. Guardini, La visione cattolica del mondo, 32.

28 Pod tim vidom i s obzirom na važnost talijansko-njemačkog teologa upozorio je A. Torres Queiruga, La rivelazione di Dio nella realizzazione dell'uomo, Borla, Roma, 1991., 165-167; usp. također C. Dotolo, Rivelazione e realtà, Hermeneutica. Annuario di filosofia e teologia (2014.), 157-170. 
jetu, povijesti. ${ }^{29}$ To znači da se kršćanstvo pretače u kulturu te da se njegova kristološka bit konstituira u kulturnu energiju ondje gdje sugerira temeljni stav unutar života. Prema tome, kršćanski Weltanschauung predstavlja i kritičko obzorje u odnosu na kulturne opcije obilježene poricanjem temeljnih vrijednosti izrečenih u kršćanstvu, te prijedlog onoga ljudskoga koje se, na tragu Isusa Krista, bori za moguće buđenje u kerygmi smrti i uskrsnuća. To je poziv i bit kršćanstva. ${ }^{30}$ Tako piše u Etici, najvećem i najznačajnijem rukopisu, načinjenom iz neobjavljenih posmrtnih djela i odgovara na predavanjima održanima u Münchenu od 1950. do 1962.: „Objava uspostavlja egzistenciju. Ona ne donosi samo učenje, ne ukazuje na smjer, ne samo da rađa red, već sve to čini zajedno [..] Što Objava želi, što proizlazi iz njezina približavanja čovjeku i iz odgovora koji iz toga dolazi, to je dakle cjelokupna egzistencija: znanje, odluka volje, red života, stav.“31

Prijevod s talijanskog Mladen Parlov

29 Guardini to jasno kaže: „Što se više kršćanstvo ponovno potvrđuje kao nešto što nije spontano i automatsko, i što će se odlučnije razlikovati od prevladavajućeg nekršćanskog poimanja života, to će se jasnije u dogmi, uz teorijski element, pojaviti i onaj praktični i egzistencijalni“. R. Guardini, La fine dell'epoca moderna, 106.

30 Jedna od konstanti teološkog promišljanja dvadesetog stoljeća bilo je pitanje o biti kršćanstva, osobito u situacijama promjene strukture vjerodostojnosti i uvjerljivosti kršćanske ponude. Za status quaestionis vidi: M. Delgado (ur.), Das Christentum der Theologen im 20. Jahrhundert. Vom 'Wesen des Christentums' zu den 'Kurzformeln des Glaubens', Verlag W. Kohlhammer, Stuttgart - Berlin - Köln, 2000. Unutar te rasprave smješta se i Guardinijevo razmišljanje koje, između ostalog, ističe svoju poziciju djelom: L'essenza del cristianesimo (1939.), Morcelliana, Brescia, 1981. Jasno proizlazi središnje mjesto kristološkog događaja za kršćanstvo, do te mjere da jedinstvenost Isusa Krista zahtijeva od vjernika radikalnost nasljedovanja koje nadilazi samu etičku dimenziju kako bi postala vizija svijeta te sposobna čitati povijest polazeći od kristološke paradigme. U odnosu na Guardinijevo razmišljanje teolog Perone primjećuje: "U tome leži otajstvo i paradoks kršćanstva: u mišljenju da to postojanje u duhu, to duhovno u-tjelovljenje u Krista, otvara stvarnost, stvarni odnos s božanskim, što ne bi bilo moguće ni zamisliti bez Kristove osobe“. U. Perone, L'essenza della religione, Queriniana, Brescia, 2015., 63.

31 R. Guardini, Etica. Lezioni all'Università di Monaco (1950-1962), Morcelliana, Brescia, ${ }^{2}$ 2003., 1049. 


\title{
CHRISTIAN WELTANSCHAUUNG AND ETHICS WITH ROMANO GUARDINI
}

\begin{abstract}
Summary
One of the merits of Romano Guardini's ideas was that he contributed to a better elaboration of the twentieth century theological thinking and its epistemological status; above all in interdisciplinary attention and the logic of dialogue. In that sense, the hermeneutic figure of Weltanschauung seems to be fruitful, with interesting development: it urges theology to think of itself and to behave as an intellectual partner among others, showing the theoretical identity that can be set to the limit of knowledge, in the heart of which there is an understanding of the mystery of the real. From this perspective, religious experience contributes to a different understanding of human condition, opening it to the revelation as a necessary prerequisite for starting a search for some important keys to reading in the interpretation of the world and history. This brings at least a double consequence. The first one is the claim of the revealing structure of reality in which religion appears as a special way of inhabiting the world, in which questions and horizons of existence are shaped. The other one is the indicator of "Christian culture" as a radical and unique perspective of man, the world and history, which on the basis of Easter event becomes the prophecy of meaning in socio-cultural processes.

Key words: Guardini, Weltunschauung, ethics, theological reflection, religious experience
\end{abstract}

